\title{
Christianity to Ecology: John Muir's Walk through America
}

Jean-Daniel Collomb

\section{OpenEdition}

Electronic version

URL: http://journals.openedition.org/transtexts/254

DOI: $10.4000 /$ transtexts.254

ISSN: 2105-2549

Publisher

Gregory B. Lee

Printed version

Date of publication: 1 December 2008

Number of pages: 100-113

ISSN: 1771-2084

Electronic reference

Jean-Daniel Collomb, « Christianity to Ecology: John Muir's Walk through America », Transtext(e)s Transcultures 跨文本跨文化 [Online], 4 | 2008, Online since 15 October 2009, connection on 19 April 2019. URL : http://journals.openedition.org/transtexts/254 ; DOI : 10.4000/transtexts.254 


\title{
Christianity to Ecology: John Muir's Walk through America
}

\author{
JEAN-DANIEL COLLOMB
}

\begin{abstract}
From a very early age the American environmentalist John Muir displayed an unusual passion for nature. His view of nature as a benevolent entity was at odds with the Judaeo-Christian culture which dominated his time. The young John Muir found it increasingly difficult to accept the kind of cultural perspective on nature which then prevailed. In 1867, after a serious accident, Muir made up his mind to devote his life to the contemplation of nature. In order to do so he decided to walk in the footsteps of his intellectual role model, the naturalist Alexander von Humboldt who had explored the Amazonian forest. Before he could do that, Muir had to walk all the way from Indiana to Florida. Muir's thousand-mile walk is the story of an individual adumbrating an ecological counter-culture of his own through the act of travelling across the American territory.
\end{abstract}

John Muir is best remembered today for the role he played in the establishment of the American national park system in the nineteenth century. He is also often described as one of the pioneers of American environmentalism. Born into a deeply religious family and brought up according to dogmatic Calvinistic tenets, John Muir displayed an unusual passion for nature from a very early age. His view of nature as a permanently benevolent entity appears to be at odds with the JudeoChristian culture which dominated his time. Indeed ever since the landing of the Founding Fathers on the coasts of Massachusetts, American people had been apt to sustain a highly antagonistic relationship to their natural environment. Relying on the message contained in the Bible, most American people tended to regard nature 
either as a sphere inhabited by evil which it was their mission to subdue and harness, or, more prosaically, as a pool of resources which God had given them a mandate to exploit in order to "grow and multiply". Such a frame of mind left little space for the aesthetic, let alone ecological, contemplation of the natural world. Instead it set the tone for a highly utilitarian culture. The young Muir found it increasingly difficult to take such a cultural perception of nature on board. After leaving the family farm he struggled to find his place in society. Magnetically drawn to forests and mountains he worked sporadically to eke out a living. In 1867, after a serious accident at a factory in Indianapolis which left him blind for two months, Muir made up his mind to devote his life to the contemplation of nature. In order to do so he decided to follow the footsteps of his intellectual role model, the German naturalist Alexander von Humboldt who had explored the Amazonian forest in the early years of the nineteenth century. But before he could do that Muir would have to walk all the way from Indiana to Florida where he planned on boarding on the first ship bound for South America. In the process he travelled through the states of Indiana, Kentucky, Georgia and Florida. There he was struck down by malarial fever which forced him to rest for several months. Eventually he found himself in too poor a condition to go to South America. Before sailing back up north, he went on a short visit to the island of Cuba.

As was his wont, John Muir kept a journal about his journey. It was published much later as A Thousand-Mile Walk to the Gulf in 1916, two years after his death. In this account of his venture across the American continent the notions of culture and transit both have a central role. What is meant by "culture" is a common trust of values, ideas and perceptions shared by the wide majority of a given society. Culture helps stick its members together and provides them with common values and a common orientation. For instance dominant attitudes as regards nature differ from one culture to another. Even more importantly, culture is a construct which stems from a long drawn-out process. It can hardly be regarded as a monolithic and static fund which cannot be altered in any way. That is the reason why the way a social group acts towards nature and the way its members regard it are more often than not cultural. Cultural values can indeed be deconstructed and remodelled on a new pattern. As such culture is subject to change. It allows for transition. In a Thousand-Mile Walk movement looms large. John Muir pursued this quintessential American activity with gusto. As Wallace Stegner, novelist and historian of the American West, once put it, movement was one of the defining feature of American life at the time of Muir's life, particularly in the western territories: "Insofar as the West was a civilization at all between the time of Lewis and Clark's explorations and about 1870, it was largely a civilization in motion, driven by dreams. The people who composed and represented it were part of a true Folk-Wandering, 
credulous, hopeful, hardy, largely uninformed". ${ }^{1}$ By travelling through America Muir seems to have been crossing a line, as if he had been encroaching on new territories and, most notably, on new ideas, hence giving rise to a new cultural outlook. To transit then can be equated with the crossing of a threshold, to entering a new place, a new era, a new culture even. The act of moving in a physical sense may accordingly be tantamount to changing one's mind, to displacing wellentrenched beliefs in order to replace them by new values and an altogether novel perception of man's place in the world. Seen in that light John Muir's thousand-mile walk is the story of a man adumbrating some sort of an ecological counter-culture of his own through the act of travelling across the American territory. Gradually his geographical transit turns into a profound cultural shift.

\section{Nature and Christianity}

Originally, Muir derived much of his own personal culture from the broader culture of the country in which he was born. In other words he was brought up in conformity with the Western Judeo-Christian culture which pervaded his native Scotland and the United States in his lifetime. Muir's father was a Campbellite, a fundamentalist offshoot of Scottish Presbyterianism. He enforced stringent religious discipline at home. As a result all aspects of Muir's youth were affected by Christianity. The young boy was well versed in Christian thinking as his father obliged him to learn the whole of the Old Testament and part of the New by heart. As a curious Wisconsin farm boy he had to circumvent his father's authority in order to quench his thirst for knowledge and read books unrelated to religious matters. Even though he did receive Christianity as a cultural heritage it was not the whole story. In the autobiography of his youth, we learn that from a very early age his attraction to nature had seemed to outweigh any other preoccupations in his mind. But then, Muir ascribes his passion for nature not to any sort of cultural tradition but rather to his natural instinct: "[...] The natural inherited wildness in our blood ran true on its glorious course as invincible and unstoppable as stars". ${ }^{2}$ According to the writer himself his early inclination towards nature owed little to culture. Such a view of nature remained etched on his memory. He remained true to it, irrespective of what the wider culture had to say about man's place in nature. As a matter of fact, as time went by, it was becoming increasingly evident that Muir was straying away from the Judeo-Christian core of values which permeated his

\footnotetext{
1 Wallace Stegner, The American West as Living Space, Ann Arbor, University of Michigan Press,1987, p. 21.

2 John Muir, The Story of my Boyhood and Youth, 1913, in John Muir, Nature Writings, New York, The Library of America, 1997, p. 7.
} 
time. By looking at nature differently Muir was going his separate way. But how different was the culture he was creating from that which was taken for granted by most of his contemporaries?

Historically speaking, Christian attitudes towards wild nature, often described as wilderness, have been rather hostile. According to William Cronon, the notion of wilderness is first and foremost a cultural construct, whose artificial character was exposed by Charles Darwin's theory of evolution. Darwin argues that the dichotomy between man and nature is a figment of man's religious imagination, an imaginary line drawn by man so as to dissociate himself from phenomena he struggles to control and understand. Over the centuries Christian thinking has developed a highly negative cultural perception of the wilderness as "[...] the antithesis of all that was good and orderly". ${ }^{3}$ In the Bible the "howling wilderness" was the place where Adam and Eve found themselves after having been driven out of Eden. The wilderness was also the place where Christ had to resist the temptations placed before him by the devil for 40 days. More generally the wilderness is often pitted against the idea of a garden. It is every Christian's task to reclaim the wilderness and convert it into a well-ordered place reminiscent of prelapsarian innocence. By contrast in wild places men are supposedly prone to lose their bearings and succumb to sin. In short, in the Judeo-Christian tradition wilderness is recurrently thought to be the seat of evil. The New England puritans, putting great emphasis on biblical study, were quick to equate the natural environment they found in America with a "howling wilderness". To them wild nature embodied evil and had to be subdued by every means possible. They passed on this idea to later generations of American pioneers. These pioneers, including those Muir rubbed shoulders with on the Wisconsin frontier of the mid-nineteenth century, considered it their mission to conquer the American wilderness and transform it entirely to suit their purposes. In the words of Roderick Nash, "in the morality play of westward expansion, wilderness was the villain, and the pioneer, as hero, relished its destruction. The transformation of a wilderness into civilization was the reward for his sacrifices, the definition of his achievement, and the source of his pride". ${ }^{4}$ Such a mindset was well-entrenched when Muir left for South America in 1867. Yet the young man was not alone in differing from the spirit of the age. He had heard about saint Francis of Assisi who many centuries before had tried to foster feelings of sympathy for animals which he deemed worthy of

\footnotetext{
3 William Cronon, « The Trouble with Wilderness, or, Getting Back to the Wrong Nature », in The Great New Wilderness Debate, J. Baird Callicott and Michael P. Nelson (eds.), Athens and London, The University of Georgia Press, 1998, p. 473.

4 Roderick F. Nash, Wilderness and the American Mind, New Haven and London, Yale University Press, [1967], 2001, p. 24-25.
} 
Christian love. But Muir was well aware that such views were largely ignored by his contemporaries. There was, however, a gradual shift in perception which had come underway owing to the combined influence of European romanticism and American transcendentalism. Ralph Waldo Emerson and Henry David Thoreau endeavoured to bestow a higher value on wild nature. Furthermore three years prior to Muir's thousand-mile walk, in 1864, Yosemite valley had been deeded by the American government to the State of California as the nation's first wildland park. This said, the rehabilitation of the wilderness remained the preserve of an educated elite and was by no means the result of a shift in values on the part of the American people as a whole, as Muir's journal of 1867 makes clear. Most American people had very little time nor interest for wild nature.

\section{The Great Escape: From Geographical to Cultural Transition}

In A Thousand-Mile Walk, the act of walking takes on rich symbolical meaning. Before departing on his trip, Muir thought it necessary to visit his family in Portage, Wisconsin, where he spent a few days. He knew that he was leaving for a long period of time. His walk can hence be seen as a real parting of ways with his family, most notably with his father. In the late 1860s it seems that Muir was in need of keeping to himself and leaving his fellow-men behind, mostly because he had had enough of the dominant mood of his time. Accordingly several journal entries begin by his announcing that he wants to flee from human presence, particularly in the early days of the trip. ${ }^{5}$ Consistent with this initial impulse Muir refused to commit to anyone throughout his journey, even declining an offer to teach at a school in Kentucky. ${ }^{6}$ Such an attitude cannot solely be accounted for by his passion for nature. There is also a measure of misanthropy in Muir's thinking. It is fair to say that the writer went through a process of disaffiliation from his fellow men. By walking south he was also walking away from humanity. From the very beginning he would talk to no one. ${ }^{7}$ Yet his misanthropic feelings only came into their own gradually as if the walk was enlarging the gap separating the young naturalist from his fellow-men. In the chapters dealing with Indiana and Kentucky Muir appears to be in two minds about the people he met. Several folks generously provided him with accommodation. He also enjoyed chats with farmers in Kentucky ${ }^{8}$, even though such acquaintances never lasted long. But after his stay in Georgia his

\footnotetext{
5 John Muir, A Thousand-Mile Walk to the Gulf of Mexico, Boston, New York, A Mariner Book, [1916], 1998, p. $2,7,8$.

6 Muir, A Thousand-Mile Walk, p. 12.

7 Muir, A Thousand-Mile Walk, p. 1.

8 Muir, A Thousand-Mile Walk, p. 6
} 
distrust towards his fellow-men took a more radical turn. When he arrived in Florida he appeared unwilling to meet anyone and immediately made for the groves. ${ }^{9}$ More than ever before Muir felt at odds with his fellow-men. For instance he disparages man's consubstantial dirtiness which, he argues, dissociates him from nature: "Man and other civilized animals are the only creatures that ever become dirty". ${ }^{10}$ At this point Muir really wanted to have nothing to do with mankind. He went as far as to bemoan his needing some food as it forced him to go back to civilization: "[...] could it be dispensed with I doubt if civilization would ever see me again". ${ }^{11}$ In Florida the process of disaffiliation came full circle. The geographical plane and the intellectual one fused together. Muir's thirst for independence and solitude verged on misanthropy.

Nevertheless, it all came at a cost. Muir's journey did indeed bear the hallmark of ascetics and moral purgation. In the years that preceded his walk, Muir had already proved to be a seasoned rambler while exploring the woods of Canada, Illinois and the Great lakes region but he had never made so bold an attempt. Evidently enough a thousand-mile walk from Indiana to Florida is a highly exacting venture. His was an itinerary of enormous proportions but the sheer length of the trip was not the whole story. Not only did he run the risk of roaming the post-Civil War south but he also had to bear gruelling conditions. He would have got robbed several times by small bands of guerrilla if it had not been for his modest appearance. Besides Muir travelled light. He describes the content of his bag after a disappointed robber hands it back to him: "[...] a comb, brush, towel, soap, a change of underclothing, a copy of Burns's poems, Milton's Paradise Lost, and a small New testament [...]". ${ }^{12}$ On several occasions Muir had to sleep rough and he often went hungry. ${ }^{13}$ So much so that when he arrived in Savannah, Georgia, the trip began to take its toll on him. To make matters worse the money package he was expecting from his brother failed to arrive. Exhausted and penniless, he resolved to go to the Bonaventure graveyard, close by, and dwell there. Every now and again he had to drink from streams or puddles. He led such a life for 6 days. His declining strengths notwithstanding he walked on undeterred and again, found himself subjected to extreme conditions in Florida. There, refusing to come in contact with his fellow-men, he tested his vital forces to the utmost. At one point, he describes himself groping for a dry spot to sleep on in the marshes in the middle of the night: "But even the sandy barren was wet, and I had to grope in the dark a long time, feeling the ground with my hands

\footnotetext{
${ }_{9}$ Muir, A Thousand-Mile Walk, p. 87.

${ }_{10}$ Muir, A Thousand-Mile Walk, p. 110.

11 Muir, A Thousand-Mile Walk, p. 95.

12 Muir, A Thousand-Mile Walk, p. 17-18.

13 Muir, A Thousand-Mile Walk, p. 21, 56.
} 
when my feet ceased to plash, before I had at last discovered a little hillock dry enough to lie down on. I ate a piece of bread that I fortunately had in my bag, drank some of the brown water about my precious hillock and lay down". ${ }^{14}$ It should be added that Muir could have been devoured by an alligator at a moment's notice. Eventually his body could take no more of this regimen and he was struck down by malarial fever. He did not go through such a perilous and exhausting experience solely on account of material necessity. Crucial to his adventure was the notion of ascetics. An eager reader of the American transcendentalists since his time at Wisconsin university, Muir had been inspired by the example set by H.D. Thoreau in Walden. In the chapter entitled "Higher Laws", Thoreau argues that for man to establish a meaningful contact with wild nature, an ascetic approach to it is required. He explains that by going hungry and blending into the natural environment, however exacting such a task might be, a man's soul could be elevated: "The repugnance to animal food is not the effect of experience, but is an instinct. It appeared more beautiful to live low and fare hard in many respects [...]. I believe that every man who has ever been earnest to preserve his higher or poetic faculties in the best conditions has been particularly inclined to abstain from animal food, and from much food of any kind". ${ }^{15}$ Muir read and approved of this passage of Walden. Above all he was willing to observe the harmony of nature and to experience life in the open to the full. Thus, when waking up with an empty stomach one morning at Bonaventure cemetery, he could think of nothing but the beauty of his surroundings: "[...] I arose refreshed, and looking about me, the morning sunbeams pouring through the oaks and gardens dripping with dew, the beauty displayed was so glorious and exhilarating that hunger and care seemed only a dream". ${ }^{16}$ With abstinence comes the reward of natural harmony. Muir deemed his humble fare undoubtedly worthwhile and he could have contemplated no other way to travel. There was, however, much more to this journey than the mere pleasure of individual development.

\section{Going Out: The Forging of an Ecological Counter-Culture}

Muir's journey across the American continent led him towards a proto-ecological frame of mind. The young naturalist prepared the ground for a part of twentiethcentury ecological thinking in America. To grasp the ecological purport of Muir's writings one must first understand the vision which underpinned his pursuit of

\footnotetext{
14 Muir, A Thousand-Mile Walk, p. 94.

15 Henry David Thoreau, Walden, New York and London, W.W. Norton \& Company, [1854], 1992, p. 143144.

16 Muir, A Thousand-Mile Walk, p. 76.
} 
science. Muir's science opened a window on the biosphere. And indeed the scientific motive behind the trip can hardly be understated. John Muir has often been portrayed as a romantic figure, intent only on marvelling at the aesthetics of nature. Nothing could be further from the truth. First and foremost Muir took a rational and scientific approach to nature. Truly he was a man of science, albeit an amateur. Reading between the lines one realizes that Muir kept abreast of the latest research in the field of botany. Mention is made for instance of the Swedish botanist, Linneaus, who shaped his field well into the nineteenth century. Muir also refers to Harvard botanist Asa Gray whose writing helped give a new orientation to botanical research in the United States. When asked by a blacksmith what had brought him to Kentucky, Muir stated it had been his botanical interest, much to the dismay of his interlocutor. He quoted as the chief motive of his journey not adventure and the quest for freedom but botany. Muir once said: "Almost everything that grows is interesting to me. [...] I love all kinds of plants, and I came down here to these Southern States to get acquainted with as many of them as possible". ${ }^{17}$ In Florida Muir dubbed his trip "my floral pilgrimage". ${ }^{18}$ Unsurprisingly there is a wealth of botanical observations throughout $A$ ThousandMile Walk. Such a propensity is worth noting since scientific knowledge is one of the prerequisites of ecology.

From his teenage years onwards Muir nurtured his own particular brand of science. In the autobiography of his youth he claims to have been greatly influenced by the German naturalist, Alexander von Humboldt. Humboldt's method shaped Muir's approach for the rest of his life. Firstly, Humboldt refused to dissociate the scientific from the aesthetic. To him, reason and beauty went hand in hand. Secondly, Humboldt put particular emphasis upon first-hand knowledge that he had gained in the field. To his mind the natural philosopher had by all means to come into direct contact with nature in order to understand it properly. Walking, therefore, appeared to him as the best means by which knowledge about the world could be obtained. This, of course, was reminiscent of the ideas set forth by Thoreau in a brief essay entitled Walking which Muir was also acquainted with. ${ }^{19}$ Most importantly, Humboldt wanted to convince his readers to embrace a holistic view of nature. He made this point clear in his monumental study of natural phenomena, aptly entitled Cosmos. In this book, he argues that nature can only be analysed as a whole. Ultimately what the naturalist should be concerned with is the cosmos. In Cosmos Humboldt urges every naturalist to study details with great care but only so as to come back to the general plane in the end, an approach which Muir eagerly

\footnotetext{
17 Muir, A Thousand-Mile Walk, p. 23.

18 Muir, A Thousand-Mile Walk, p. 85.

19 Henry David Thoreau, Walking, Dodo Press, [1854], 2006.
} 
took on board. To such an extent that his journal sometimes sounds like a tribute to Humboldtian science: "There is no fragment in all nature, for every relative fragment of one thing is a full harmonious unit in itself. All together form the one grand palimpsest of the world". ${ }^{20}$ Muir craved to follow the footsteps of his German predecessor. Chief among his ideas, therefore, was the notion that natural harmony, unity and beauty were to be observed at close range and contemplated from a general plane.

Implicitly, Humboldtian science paves the way for an ecological perception of the world. In ecology nature is indeed seen as oikos, the Greek for household. ${ }^{21}$ The science of ecology consists in regarding nature as a whole, namely as a biosphere (as it was later to be called) made up of interrelated parts. According to such a perception, every single living being is linked to the rest of the biosphere and can, if modified, have an impact on the integrity of the whole. Accordingly it seems pointless and self-defeating to take a fragmentary approach to natural phenomena. On reading A Thousand-Mile Walk one can hardly deny that John Muir was a forerunner of ecological thinking. The front-page of his journal fittingly bears an inscription which echoes Humboldt's Cosmos and announces twentieth-century ecology: "John Muir, Earth-planet, Universe". ${ }^{22}$ This epigraph set him in the context in which he was to investigate nature. In that respect his six-day stay at Bonaventure graveyard some four miles away from Savannah was an intellectual watershed.

Entitled "Camping Among the Tombs", chapter IV marks Muir's ecological epiphany, the writer's decisive transition towards a new cultural assessment of man's place in nature. As the money package which Muir expected failed to arrive, he was loath to be put up at a hotel and therefore made for the Bonaventure graveyard. There, he experienced some sort of a revelation, as is made evident by his recollection of the place:

"I gazed awe-stricken as one new arrived from another world. Bonaventure is called a graveyard, a town of the dead, but the few graves are powerless in such a depth of life. The rippling of waters, the song of birds, the joyous confidence of flowers, the calm, undisturbable grandeur of the oaks mark this place of graves as one of the Lord's most favored abodes of life and light" ${ }^{23}$

At first glance Muir's prose sounds like a romantic praise of natural harmony but on further examination, one comes to the realization that his judgement stems from

\footnotetext{
20 Muir, A Thousand-Mile Walk, p. 164.

21 The term was coined by the German naturalist Ernst Haeckel.

${ }_{22}$ Muir, A Thousand-Mile Walk, p. xiii.

${ }_{23}$ Muir, A Thousand-Mile Walk, p. 69.
} 
his scientific bias. Muir's treatment of Bonaventure bears the hallmark of Charles Darwin's theory of evolution, disclosed to the public only a few years before, in 1859. The landscape Muir depicts is one of a natural environment in flux, buoyant with life and driven by an ever-creative principle: "Arching grasses come one by one; seeds come flying on downy wings, silent as fate, to give life's dearest beauty for the ashes of art; and strong evergreen arms laden with ferns and tillandsia drapery is spread over all -Life at work everywhere, obliterating all memory of the confusion of man". ${ }^{24}$ Such a perception of natural life was in keeping with Darwin's emphasis upon change and adaptation which, he claimed, characterized the process of evolution. Muir followed in Darwin's footsteps in yet another respect. The Origin of Species implicitly disproved the notion of a hierarchy of species which had long served to label man as God's chosen creature. One of the most revolutionary aspects of evolutionism was that it knocked down the barrier which, in the Christian tradition, had separated man from all other living beings. Muir enthusiastically welcomed such a questioning of man's special status. He held that man was a member of the biosphere in his own right but no more so than any other beings. Inspired by The Origin of Species he took Darwin's theory to its logical and subversive conclusion by stating: "We all are only microscopic animalcula". ${ }^{25 M u i r}$ was upholding thereby no less than a cultural revolution which had originated with the publication of Darwin's theory eight years before he set for the Gulf of Mexico.

Hence, in 1867, Muir can really be said to have been at the vanguard of a nascent form of ecological thinking. His understanding of nature as oikos was already so well formed that it led him to value insects and microscopic beings as important members of the biosphere when they were usually discarded as a mere nuisance or pests which most people were eager to get rid of. It is worth noting that Muir set forth this radically new idea almost a century before American ecologist Rachel Carson popularized such views in her much-acclaimed Silent Springs (1962). ${ }^{26}$ Several generations before Carson, Muir advocated the role of insects in nature's balance: "And what creature of all that the Lord has taken the pains to make is not essential to the completeness of that unit - the cosmos? The universe would be incomplete without man; but it would also be incomplete without the smallest transmicroscopic creature that dwells beyond our conceitful eyes and knowledge". ${ }^{27}$ At this point of his transit across America Muir had strayed so far away from the core values of his culture that he felt disaffiliated from it, to such an extent that he slid into sheer misanthropy and wished that there were no human

\footnotetext{
24 Muir, A Thousand-Mile Walk, p. 71-72.

25 Muir, A Thousand-Mile Walk, p. 103.

26 Rachel Carson, Silent Springs, London, Penguin Books, [1962], 1999.

27 Muir, A Thousand-Mile Walk, p. 139.
} 
creatures left to unsettle the harmony of nature. More interestingly Muir was henceforth prepared to draw all the logical conclusions as to what he considered the errors and the limitations of Judeo-Christian culture.

As a matter of fact, in so doing Muir was laying the ground for the work of another major figure of twentieth-century environmentalism. A Thousand-Mile Walk announced the theory of land-community developed by Aldo Leopold in A Sand County Almanac, published in 1949. Through his plea for "land-ethics", Leopold intended to treat other living beings with respect and care as members of a landcommunity united by an ecological bond. In this comprehensive scheme no animal or plant ought to be disparaged since every living being, including predators, had a part to play in the economy of nature. Several decades before Leopold Muir's shifting cultural vision prompted him to foster a rehabilitation of predators. Muir's contemporaries were inclined to regard predators as evil creatures to be wiped out. As such alligators were much-maligned creatures, said to be the very embodiment of cruelty and treachery. In the Florida chapter Muir seeks to reverse this trend by writing several pages in praise of the alligator. He does not deny the fact that alligators are no friends of men. However, to him, that is no reason to attack, or even disparage them. They belong in the biosphere, just like any other living being. According to Muir, man's hate for predators results from a lack of knowledge in the ways of nature, in what Ralph Waldo Emerson once referred to as "the method of nature", namely the harmonious and balanced order which nature invariably attains when left to its own devices. Besides his curt critique of man's narrowmindedness, Muir strove to demonstrate that far from being a nuisance to be eliminated, predators were necessary for the cycle of natural life. He argues that predators have a part to play in the greater economy of nature. That is why Muir did his utmost to foster a feeling of empathy towards all predators, which deserved to be treated as equal and rightful members of the land-community.

By such an unexpected statement Muir was running counter to the biblical image of the "howling wilderness" where evil creatures prowled and lurked. The latter perception, highly pessimistic in tone and content, can clearly be pitted against Muir's repeated endeavours to establish a bond between man and other living beings. There is no denying, therefore, that $A$ Thousand-Mile Walk contributed to the concept of land-community which Leopold coined in the twentieth-century. It should come as no surprise that Leopold read Muir and claimed to have been influenced by him. There is every reason to believe that Leopold was impressed by Muir's impassioned advocacy of every creature's right to exist in nature: "From the dust of the earth, from the common elementary fund, the Creator has made homo sapiens. From the same material he has made every other creature, however noxious 
and insignificant to us. They are our earth-born companions and our fellow mortals." 28 Inspired by Darwin's example Muir tried to do away with the border separating man from the rest of nature. A few decades later Aldo Leopold would follow suit. Nevertheless when he expounded his ecological views, Muir was also painfully aware that his writings fell beyond the pale of American culture. In other words, he knew what to expect from his contemporaries: "The fearfully good, the orthodox, of this laborious patch-work civilization cry "Heresy' on every one whose sympathies reach a single hair's breadth beyond the boundary epidermis of our own species". ${ }^{29}$ Such misgivings about his contemporaries' reaction led him to bring an indictment against the values which prevailed in the United States during the second half of the nineteenth century. First of all Muir came to question the American consensus on utilitarianism. In nineteenth-century America utilitarianism held sway and materialistic impulses were rampant. Muir had had several opportunities to observe these tendencies at first hand as he was brought up on the American Frontier where tilling and improving the land were the chief activities people pursued. A man was then expected to become a farmer or choose a trade, make a living and shift for himself. Muir went in the opposite direction and thus found himself at odds with the spirit of the age. Several people he met on his way to Florida discarded the motives behind his journey as pointless and ridiculed his passion for botany. A Kentuckian blacksmith lectured him on the subject, trying to convince him to put an end to his excursion and do something useful: "You look like a strong-minded man [...] and surely you are able to do something better than wander over the country and look at weeds and blossoms. [...] Picking up blossoms doesn't seem to be a man's work at all in any kind of times". ${ }^{30}$ Muir was left unimpressed by such remonstrance. Further on, he was to make some ironical comments upon another farmer's utilitarian tirade. ${ }^{31}$ Towards the end of his journal, the reign of utilitarianism in American life comes in for much criticism: "A numerous class of men are painfully astonished whenever they find anything, living or dead, in all God's universe, which they cannot eat or render in some way what they call useful to themselves". ${ }^{32}$ It appears that Muir had had enough of the crass materialism of the Frontier. To him virtually no room was made for the life of the mind for its own sake or for the enjoyment of beauty. This, however, is not the main critique Muir levelled at American culture.

Above all, A Thousand-Mile Walk can be seen as an onslaught on anthropocentrism.

\footnotetext{
28 Muir, A Thousand-Mile Walk, p. 139.

${ }^{29}$ Muir, A Thousand-Mile Walk, p. 139

30 Muir, A Thousand-Mile Walk, p. 24.

31 Muir, A Thousand-Mile Walk, p. 38.

32 Muir, A Thousand-Mile Walk, p. 136.
} 
Muir sought to refute the centrality of mankind in nature. In an ironical fashion, he resorts several times to the expression "Lord man". ${ }^{33}$ As his journey drew on Muir did his best to deflate the hubristic tendencies of modern man by presenting wild nature as infinitely superior to civilization, a point he was to make again and again throughout his literary career. To him the works of men were nothing compared with the stately beauty of nature. Going from there Muir got on with the meditating process engaged at Bonaventure when he arrived in Florida. While admiring the plants he saw there, he came to question the Judeo-Christian teachings as regards nature: "They tell us that plants are perishable, soulless creatures, that only man is immortal, etc.; but this, I think, is something that we know nearly nothing about. Anyhow, this palm was indescribably impressive and told me grander things than I ever got from a human priest" ${ }^{34}$ Muir's ecological epiphany comes full circle. He disparages man's arrogance and values the book of nature more than Christian teachings. His walk through America led him to distance himself from Western culture: "The world, we are told, was made especially for men - a presumption not supported by all the facts". ${ }^{35}$ Muir also argues against the Judeo-Christian rationale which puts natural resources at the mercy of man, whose task it is to reclaim the wilderness. Muir wants to force his readers to confront the cultural contradictions of Christian anthropocentrism. By a series of rhetorical questions he endeavours to expose what he regards as its inconsistencies:

“[...] if we should ask these profound expositors of God's intentions, how about those man-eating animals - lions, tigers, alligators - which smack their lips over raw man? Or about those myriads of noxious insects that destroy labor and drink his blood? Doubtless man was intended for food and drink for all these? Oh, no! Not at all! These are unresolvable difficulties connected with Eden's apple and the Devil. Why does water drown its lord? [...] Why are so many plants and fishes deadly enemies? Why is the lord of creation subjected to the same laws of life as his subjects? Oh, all these things are satanic, or in some way connected with the first garden". ${ }^{36}$

Put simply, man is not God's chosen creature, Muir argues. He is instead only one of God's creatures. The upshot is that Muir urges restraint on his contemporaries, several decades before American environmentalism came in full swing. He strikes a jarring note in the age of progress by asserting that man does not belong in every corner of the globe and cannot rule supreme over all areas:

\footnotetext{
${ }_{33}$ Muir, A Thousand-Mile Walk, p. 133, 157.

${ }_{34}$ Muir, A Thousand-Mile Walk, p. 92.

35 Muir, A Thousand-Mile Walk, p. 136.

36 Muir, A Thousand-Mile Walk, p. 138.
} 
“[...] even of the land only a small portion is free to man, and if he, among other journeys on forbidden paths, ventures among the ice lands and hot lands, or up in the air in balloon bubbles, or on the ocean in ships, or down into it a little way in smothering diving-bells - in all such small adventures man is admonished and often punished in ways which clearly show him that he is in places for which, to use an approved phrase, he was never designed" ${ }^{37}$

This foretells twentieth-century ecological thinking with its sense of the limitations of economic development and its emphasis upon humbleness as regards the prospects of human activity.

\section{Conclusion: Cultural Change}

In A Thousand-Mile Walk Muir is thus coming to an ecological awareness. In the process he questions many well-entrenched beliefs which western Christians had entertained about nature for centuries. Nevertheless his rejection of Christianity should by no means be overstated. Among the few things he carried in his bag was a copy of the New Testament, which he was to hold on to in many of his subsequent excursions. In his journal Muir still resorts to biblical imagery and he frequently uses the term "God" and "divine" in a highly positive sense. It seems fair to say therefore that Muir did not cast off his Christian heritage altogether. In some respects Christian thinking induced him to be more humble and to be fully aware of the hubristic tendencies of modernity. In all likelihood Muir intended to reshape Christianity in a way which was more congenial to nature.

37 Muir, A Thousand-Mile Walk, p. 179. 